joining unions. ${ }^{79}$ The passing of such legislation, if constitutional, would offer no real solution to the management-foreman problem and would only lead to the sort of strife that the Wagner Act was designed to avoid. ${ }^{80}$

\title{
THE SHERMAN ACT AND THE MOTION PICTURE INDUSTRY
}

The application of the Sherman Act to the motion picture industry has been long continued and erratic. This uncertainty as to the position of the industry within the framework of the antitrust laws has been most noticeable during the past eight years. In 1938 the Government brought a suit against the eight major producer-distributors the main purpose of which was to divest five of the defendants of their exhibition houses. ${ }^{x}$ In 1940 the Government acquiesced in a consent decree under which the industry was given three years in which to govern itself. ${ }^{2}$ Currently the Government is once again seeking to divest the socalled majors of their exhibition interest. ${ }^{3}$ The merit of the consent decree is basic to the present dispute. The Government premises its request for divestiture upon the inadequacy of the decree. The defendants insist that the decree was a satisfactory solution to the complex of problems which resulted from the

79 See Northrup, Unionization of Foremen, 21 Harv. Bus. Rev. 496, 504 (r943).

${ }^{80}$ Chairman Herzog, in his testimony on the Case Bill, op. cit. supra, note 77 , at 880 , called attention to the following possible courses Congress might take:

"One would be to leave the Wagner Act in its present form, relying upon the Board and the courts to determine which policy is most consistent with the Act. A second would be to protect supervisory employees against discrimination but not to require employers to bargain with the union they might select. A third would be to require employers to bargain with an independent, unaffiliated union of supervisory employees, but to remove the obligation where foremen select a union affiliated with an organization chosen by rank and file employees. A fourth alternative would be to adopt the bill as it passed the House. A fifth would be to change the definition of supervisory employee so as to afford Wagner Act protection to minor supervisory employees only."

I United States v. Paramount Pictures, Civil Action No. 87-273 (D.C. N.Y., 1938). Of the eight defendants, Twentieth-Century Fox, Loew's, Paramount Pictures, Radio-KeithOrpheum, and Warner Brothers (the "Big Five") are engaged in both the production and distribution of motion pictures and also have extensive holdings in the exhibition end of the industry. The other defendants, known as the "Little Three," are Columbia Pictures, Universal Corporation, and United Artists Corporation. Columbia and Universal engage in the production and distribution of film but do not operate any theaters. United Artists distributes motion pictures. See Plaintiff's Trial Brief, filed September, $x 945$, United States v. Paramount Pictures, Civil Action No. 87-273 (D.C. N.Y., I938) (hereinafter referred to as Plaintiff's First Brief).

2 C.C.H. Trade Reg. Serv. (8th ed., x940) $\Upsilon_{25,558}$.

3 By section 2I of the consent decree, the Government agreed to refrain from divorcement proceedings for three years. At the expiration of this period negotiations for a new decree were commenced. Since the producer-exhibitors refused to agree to divestiture, which the Government regarded as essential, the case was again brought to trial. Plaintiff's First Brief 4 . 
attempt to apply the Sherman Act to the motion picture industry. ${ }^{4}$ It is the purpose of this note to analyze the r 940 consent decree in the light of the Sherman Act and to consider the sufficiency of the Government's request for divestiture. A scrutiny of the decree will suggest why the Government has now returned to the position assumed in I938. It will also serve to point up the implications of the Government's concentration upon divestiture as the main prerequisite to the operation of competitive forces within the industry. It is possible that this emphasis may lead the Government, even if it is successful in obtaining divestiture, to agree to much of the industrial system which the decree accepted or established.

By 1938 the motion picture industry had put its tumultuous adolescence behind it and was operating in a rigid, if not completely disciplined, maturity. Out of the early struggle and confusion a definite pattern of control had developed. The production, distribution, and exhibition of motion pictures was dominated by eight organizations. Five of these so-called majors either owned or were affiliated with circuits of exhibition houses. ${ }^{5}$ Through this integrated system the large share of the industry's capital and income was channeled. ${ }^{6}$ As vertical affiliation progressed, there was combination at the exhibitor level into circuits of theaters not controlled by the majors. ${ }^{7}$ Although the great majority of the theaters remained independent, the vertical integration and horizontal combination, reinforced by unique trade practices, resulted in a steady deterioration of the position of the independent exhibitor. By exercising what they claim to be their copyright privileges, the major producer-distributors were able to impose upon the industry practices which insured the dominance of the majors. These trade practices were incorporated into the license contracts

4 "... the consent decree stands as recognition of an appropriate way to deal with many of these matters, approved by the court and by the Government." Argument for Paramount, Arguments, p. 85, United States v. Paramount Pictures, Civil Action No. 87-273 (D.C. N.Y., I938) (hereinafter referred to as Arguments).

${ }^{5}$ See note I, supra.

'The Big Five and their three satellites receive a major portion of the profits at each level of the industry. They produce over 70 per cent of the domestic features. So complete is their control over distribution that no independent distributor has ever released more than I per cent of the features in any year, while the total features released by all independent exhibitors has never exceeded 5 per cent. Temporary National Economic Committee, United States Senate, Monograph 43, The Motion Picture Industry-A Pattern of Control 8-9 (I94I). At the exhibition level, the Big Five, while owning only I6 per cent of the nation's 17,000 theaters, control more than 80 per cent of the metropolitan first-run houses. They control exhibition in all cities with populations over $1,000,000$ and in over 70 per cent of the next 375 cities (pop. 25,000 to $I, 000,000$ ). In cities of 250,000 affliated theaters have secured as much as two-thirds of the total admissions paid. Ibid., at Ir. :

7 In several instances these independent circuits have almost completely suppressed competition within the areas in which they operate. See United States v. Crescent Amusement Co., 323 U.S. 173 (1945); United States v. Schine Chain Theaters, C.C.H. Trade Reg. Serv. (9th ed., 1945) $957,4{ }^{13}$ (D.C. N.Y., I945). It should be noted, however, that the gross annual receipts of the RKO chain, the least extensive of the Big Five, are estimated to be more than five times as great as those of any independent circuit. Plaintiff's First Brief, App. A, at to. 
entered into between the distributor and the exhibitor. Films were licensed in advance of their production and in blocks covering all or a large percentage of the contemplated production for the following season. Theaters were roughly classified according to their merits as revenue producers, and were allotted "runs." First-run rights were generally allotted to the large metropolitan theaters which were affiliated with the producer-distributors. ${ }^{8}$ In order to protect the high admission prices charged by the first-run theaters from competition of subsequent runs, a period of "clearance" was established between successive runs. ${ }^{9}$ The leverage exerted by the major producers through control of the most desirable outlets effectively guaranteed the operation of these practices..$^{x 0}$ The industry had become a hierarchy in which each member was assigned a definite status. ${ }^{\text {II }}$ The rigidity of the system effectively discouraged the entrance of new

${ }^{8}$ The Government's estimates, based upon the testimony of a Loew's executive, are that $7 \mathrm{I}$ per cent of all the first-run theaters in ninety-two major cities are affiliated with one or more of the defendants. Plaintiff's Brief, filed December, I945, P. I4, United States v. Paramount Pictures, Civil Action No. 87-273 (D.C. N.Y., 1938) (hereinafter referred to as Plaintiff's Second Brief).

9 In partial consideration for the rental paid by a prior-run exhibitor the distributor agreed in the license contract to withhold each picture from other exhibitors in the same area for a specified period of time commencing with the expiration of the original exhibitor's run. Frequently, these time and area clearance schedules were expressly geared to admission prices. In Minneapolis, for example, the following provisions were incorporated in license agreements between RKO and Paramount: " 28 days over Uptown, 42 days over 30 cent houses, 56 days over 25 cent houses, 70 days over 20 cent houses. . . . " Plaintiff's First Brief, at 20. The provisions in the license agreements for runs and clearance were supplemented by provisions establishing minimum prices which could be charged by the theater exhibiting the film. Furthermore, under the license contract the distributor had the right to audit the exhibitor's receipts from films which were licensed on a percentage basis, and provision was made for reports on the admission prices charged and the number of admissions sold. Each license agreement stipulated that subsequent run theaters could not advertise a coming attraction until after its first-run engagement had been concluded. Samples of the license agreements of each distributor-defendant appear in Plaintiff's First Brief, App. B.

ro The Government's allegations of discrimination and monopoly have not been based solely upon the ownership of theaters by the defendants. The Government also alleges that the monopolistic structure of the industry has been maintained by means of cross-licensing agreements between the defendants. "By cross-licensing we do not mean the execution of a single agreement by two distributor members of these combinations with two or more exhibitor members. What happens is that Loew, for example, as a distributor, licenses its films to Paramount, as an exhibitor, by agreements which are generally separately executed by nominally different corporate entities than those involved in the license agreements made by Paramount as a distributor with the theatres controlled by Loew..... Inasmuch as these licenses generally provide for the computation of film rental in terms of a percentage of the gross receipts realized up to a certain figure calculated to yield the exhibitor an agreed margin of profit plus an equal sharing of receipts in excess of that figure, their net effect is to give each combination a share in the theatre operating profits of the others and a vested interest in promoting the business of theatres affiliated with these combinations at the expense of independent competitors." Plaintiff's First Brief 21-22.

"One example of the stratification in the industry is the "Chicago System." Films are first exhibited in the large "Loop" theaters. After this run there is a waiting period of three weeks during which the film is not exhibited in the city. The film is then given to a succession of outlying theaters according to their classification as A, B, or C "pre-release" or "general release" theaters. Each subsequent run is under obligation to maintain certain minimum 
capital and prevented the operation of competitive forces within the industry. Although a continual stream of state and federal antitrust suits by private parties $^{x^{2}}$ and the Government ${ }^{x_{3}}$ suggested the extent to which an anti-competitive pattern had been established in the industry, the suits did not challenge the

prices. If the exhibitor violates any of the provisions of his license respecting runs, prices, or clearances, he forfeits his license.

The difficulty facing any independent theater-owner in Chicago who attempted to secure a more advantageous run has received public attention in connection with the successful triple-damage action recently brought against the "majors" by the owner of an independent theater. The plaintiff complained of the concerted refusals by the distributor-defendants to allot her theater a "C pre-release" classification, and was awarded a judgment of $\$ 360,000$. The circuit court, while conceding that a jury might find the Chicago system an illegal conspiracy, reversed the award on the ground that damages had not been adequately proved. Bigelow v. RKO Radio Pictures, I50 F. 2d 877 (C.C.A. 7 th, 1945). On appeal to the Supreme Court, the judgment of the circuit court was reversed and the original award affirmed. 66 Sup. Ct. 574 (1946).

${ }^{12}$ Sec, for example, Love v. Kozy Theater Co., I93 Ky. 336, 236 S.W. 243 (1921) (specific performance of lease refused on ground that directors of local circuit were using plaintiff's theater to monopolize exhibition); Peekskill Theatre, Inc. v. Advance Theatrical Co. of New York, 206 App. Div. 138, 200 N.Y. Supp. 726 (1923) (injunction granted against exhibitors restraining them from coercing distributors into boycotting the plaintiff); Majestic Theatre Co. v. United Artists Corp., 43 F. 2d 99I (D.C. Conn., I930) (concerted refusal to deal except under terms of standard contract held an illegal conspiracy); Youngclaus v. Omaha Film Board of Trade, 6o F. 2d 538 (D.C. Neb., 1932) (distributors' uniform clearance schedules held an unreasonable restraint); Fraxam Amusement Corp. v. Skouras Theatre Corp., II3 N.J. Eq. 509, I67 Atl. 672 (I933) (overbuying by affiliated circuits not sufficient grounds for preliminary injunction); Glass v. Hoblitzelle, 83 S.W. 2d 796 (Tex. Civ. App., 1935) (prior run exhibitor contracting with distributor to impose minimum-price restrictions on plaintiff; state laws held inapplicable since commerce was interstate); First National Pictures v. Robison, $72 \mathrm{~F}$. 2d 37 (C.C.A. gth, 1934) (alteration of plaintiff's run held no ground for recovery).

${ }_{3}$ Suits by the Department of Justice were foreshadowed by the attempts of the Federal Trade Commission to curb the aggressive tactics of three of the most rapidly expanding organizations. The Stanley Booking Corporation, Famous Players-Lasky Corporation, and the West Coast Theaters were ordered to discontinue practices such as block booking, theater acquisitions, and secondary pressures, through which they had exerted purchasing power in order to suppress competitors. See Matter of Stanley Booking Co., I F.T.C. 2 I 2 (I9I8); Matter of Famous Players-Lasky Corp., II F.T.C. I87 (I927), rev'd sub nom., Federal Trade Com'n v. Paramount Famous-Lasky Corp., 57 F. 2d 152 (C.C.A. 2d, 1932); Matter of West Coast Theatres, I 2 F.T.C. 383 (r929); Matter of West Coast Theatres, I2 F.T.C. 436 (I929).

The Antitrust Division entered the arena in I928. United States v. First National Pictures, 282 U.S. 44 (I930), and Paramount Famous-Lasky Corp. v. United States, 282 U.S. 30 ( $193^{\circ}$ ), outlawed the standard contracts which distributors had imposed on all exhibitors. Under threat of criminal prosecution several consent decrees were obtained enjoining practices similar to those which had concerned the Federal Trade Commission. See United States v. Balaban \& Katz Corp., C.C.H. Trade Reg. Serv. (7th Ed. 1932) I700I (D.C. Ill., 1932); United States v. West Coast Theaters, C.C.H. Trade Reg. Serv. (Supp. Vol. IV, 1930) T4206 $_{4}$ (D.C. Cal., I93o); United States v. Fox Theaters Corp., C.C.H. Trade Reg. Serv. (Supp. Vol. III, I93I) I โ3I25, 3127 (D.C. N.Y., I93I) (ordering divestiture of a controlling interest in Loew's stock).

Contempt proceedings were subsequently filed for violation of the last two decrees. These were settled during the negotiations leading to the present consent decree, and the former decrees suspended for such time as the present decree remained in effect. For a more extensive summary of the Government's activities previous to 1938, sec Plaintiff's First Brief, App. C, at $112-50$. 
basic structure of the industry. They were directed against specific trade abuses, were only partially successful, ${ }^{x_{4}}$ and did not attack the integration of production and exhibition which was the keystone of the industry's structure..$^{15}$

It was against this system of integration and alleged discrimination that the Government moved in 1938 . The suit began as a demand for a radical alteration of the entire structure of the industry, without which, it was asserted, the discriminatory practices could not be eliminated and competition could not be insured. ${ }^{16}$ The result was the I940 consent decree. ${ }^{77}$ The core of the decree was an elaborate and unique system of arbitration ${ }^{\mathrm{I}}$ by means of which independent . exhibitors could assert their claims that runs and clearances were discriminatory, ${ }^{19}$ or that the distributor-defendants were resorting to unfair practices specified in the decree..$^{20}$ The arbitration boards were given the authority to determine whether a particular clearance offered an independent exhibitor was reasonable in the light of certain criteria established in the decree, ${ }^{2 \mathrm{x}}$ and whether

14 Private suits have been discouraged by decisions that, in the absence of the conspiracy, the producer's copyright entitles him to distribute his product as he sees fit. Gary Theatre Co. v. Columbia Pictures Corp., I20 F. 2d 89 I (C.C.A. 7th, 194I); Westway Theatre v. Twentieth Century-Fox Film Corp., 3o F. Supp. 830 (Md., I940), aff'd $x r_{3}$ F. 2d 932 (C.C.A. 4th, 1940). A uniform pattern of distribution usually has not been held sufficient evidence for an inference of conspiracy. See 36 Col. L. Rev. 635, 643-44 (1936). But see note 45 , infra, and accompanying text.

I5 In Igr6 the motion-picture patent trust was held to violate the Sherman Act. United States v. Motion Picture Patents Co., 225 Fed. 800 (D.C. Pa., 1915), app. dismissed, 247 U.S. 524 (19I8). This was the only suit in which the Government secured a drastic alteration of the structure of the industry. Following the dissolution of the patent monopoly the copyright became the basis of the restrictions placed upon the right to exhibit films.

${ }^{16}$ Antitrust Division, Public Statement, July 20, 1938. In addition to divestiture injunctive relief was also sought against specific unfair and discriminatory practices. See page $35 x$, infra.

${ }^{17}$ The decree ran against the five producer-exhibitors only. It provided, however, that unless similar relief was obtained from the nonconsenting defendants within one year from the date when the decree went into operation, the block-of-five and trade-showing provisions (see page $35 \mathrm{I}$, infra) should be suspended. Consent decree $\$$ I2 (a), (b). Although no action was taken against the "Little Three," the consenting defendants allegedly continued to market films in accordance with the decree. Arguments, I23.

${ }^{18}$ Administration of the arbitration system was entrusted to the American Arbitration Association. Arbitration tribunals were established in each of the thirty-two cities in which three or more of the distributor-defendants maintained film exchanges. Each tribunal consisted of a panel of ten men selected by the Association; but no person having any connection with the movie industry was to be employed in any capacity by the tribunals. General appellate jurisdiction of all arbitration was vested in a three-man appeal board sitting in New York. Its members, appointed by the district court, were required to be "person[s] of known impartiality and distinction." Consent decree $\$ 22$.

r9 Consent decree $\S 6$ (refusal to license on any run), $\S 8$ (unreasonable clearance), $\S$ ro (unfair run). The opportunity to arbitrate was open only to exhibitors and in the case of run discrimination only to independent exhibitors who could meet certain specified qualifications. See page 355 , infra.

${ }^{20}$ Ibid., $\S \S 4,5$ (selling in blocks of more than five pictures), $\S 9$ (withholding prints).

a1 Tbid., $\$ 8$. 
an exhibitor was entitled to a more favorable run. ${ }^{22}$ The distributors were enjoined conditionally from blind selling ${ }^{23}$ and booking in blocks of more than five pictures or from conditioning the licensing of feature pictures on the purchase of "shorts." ${ }_{24}$ The distributors were further enjoined from making any general expansion, ${ }^{25}$ and provision was made for the alteration of the decree in the event that different terms were imposed upon the non-theater-owning producers who did not consent to the decree. ${ }^{26}$ The decree was to operate for a period of three years, the Government reserving the right to reopen the case at the end of that time. The Government agreed, however, not to request divestiture or the dissolution of any producer-defendant or of any exhibitor affiliated with the defendants during the period of the operation of the decree. ${ }^{27}$

Such were the broad outlines of the decree. It was accepted with restrained jubilation in Hollywood and in New York, ${ }^{28}$ and with satisfaction and assurance in Washington. ${ }^{29}$ Indeed, the decree was heralded by participants and onlookers as a farsighted innovation in the enforcement of the antitrust laws..$^{30}$ The Government, it was said, had at last turned "a weapon usually employed for trust-busting to a more constructive use." ${ }^{\mathrm{x}}$

This almost unanimous approbation makes even more striking the fact that the decree was the antithesis of the ideals of competition and kinetic industrialism reflected in the antitrust laws. The decree, conceived during the most vigorous period of antitrust enforcement since the passage of the Sherman Act, was a blue-print of industrial cartelization. It represented, as its proponents

23 Ibid., \& 1o.

23 Tbid., 83.

24 Ibid., \$4(b).
25 Ibid., \$ Ir.

${ }^{26}$ Ibid., $8 \mathrm{I} 2$; see note I7, supra.

27 Ibid., \$2r.

${ }^{28}$ See, for example, the comments of Austin Keough, Vice-President, Secretary, and General Counsel of Paramount. Keough, A Distributor Discusses the Motion Picture Consent Decree and Arbitration, 5 Arb. J. 33 (r94x).

39 "The establishment of a system of arbitration to implement the slower and more expensive remedy of private suits under the anti-trust laws supplies a long-felt need in the motion-picture industry. It is to be noted, however, that the decree takes away no existing legal rights of any exhibitor under the anti-trust laws. It provides an additional forum for the settlement of disputes for which no provisions have heretofore been made. Properly administered, it should put an end to disputes between distributors and exhibitors which have been a constant source of discord and friction in the past and should result in placing the industry on a fair competitive basis." Antitrust Division, Public Statement, pp. 8, 9, October 29, 1940; see Hayes, Provisions of the Consent Decree, 5 Arb. J. I5 (r94I).

${ }^{30}$ See Symposium on Arbitration in the Motion-Picture Industry, 5 Arb. J. Io (rg4r); 50 Yale L. J. 854 (194I). It is ironic that the decree should have pleased all but the one group in whose behalf the suit was allegedly undertaken - the independent exhibitors. Their representatives appeared before the court when the decree was announced and uniformly opposed its adoption. Motion Picture Herald, p. I8. (Nov. 23, x940). Typical of the exhibitor reaction was the statement issued by Abram F. Myers, head of the Allied States Association of Motion Picture Exhibitors of America, characterizing the decree as "a capitulation by the Department of Justice as astonishing as it is complete." Motion Picture Herald, pp. I7, 40. (Nov. 9, 1940).

$$
{ }^{37} \text { Hamilton, A Judicial Process for Industry, } 5 \text { Arb. J. } 50 \text { (I94I). }
$$


pointed out, "an unprecedented form of industrial self-regulation"; 32 it was "an instrument of industrial government." 33 The decree not only accepted the pattern already established in the industry; through governmental sanction, it dignified and gave rigidity to that pattern. ${ }^{34}$

An analysis of some of the provisions of the decree will illustrate the extent to which the decree represented a departure from the competitive pattern that the Sherman Act was designed to achieve in this country.

Perhaps the most striking feature of the decree was the provision for arbitration-a startling innovation in the enforcement of the antitrust law. ${ }^{35}$

Arbitration may operate at two stages in the commercial process. Parties to a contract may provide that any dispute, as to either the meaning of the terms of a contract or the application of certain facts to those terms, shall be arbitrated. Such arbitration, though acclaimed as a speedy and inexpensive method for settling commercial disputes, has been employed as a device for evading judicial scrutiny of agreements which might violate the Sherman Act. ${ }^{36}$ Frequent use has been made of such arbitration clauses to impose the will of the dominant group upon other members of an industry. In this country one example of this use of the arbitration clause has been in connection with patent agreements; ${ }^{37}$ in Europe most cartel agreements provide for the arbitration of disputes between members of the cartel. ${ }^{38}$ The movie industry itself has a

${ }^{2}$ Arbitration in the Motion-Picture Industry, 5 Arb. J. Io, 14 (194r).

33 Hamilton, op. cit. supra, note $3 r$, at 58 .

34 In many respects the decree was similar to the codification attempted under the National Industrial Recovery Administration when the Motion-Picture-Code Authority initiated a set of over-all regulations to govern practices within the industry and erected a system of arbitration tribunals for the adjustment of exhibitor and distributor grievances. Nizer, New Courts of Industry (1935). The Authority attempted to draft uniform clearance and zoning schedules, but abandoned this almost impossible task, and relied on the arbitration boards, acting under specified standards, to work out justice in individual cases. The code differed from the decree, however, by regarding clearance disputes as a contest between exhibitors only; the interest of distributors in affiliated theaters was apparently ignored. Ibid., at $98-\mathrm{r} 20$.

${ }_{35}$ Arbitration seemed far more in keeping with the atmosphere of the NRA. Even the code authority, with its emphasis upon self-regulation, espoused the view that runs should be determined by negotiation rather than by arbitration. Ibid., at 144 .

${ }^{36}$ For a thorough discussion of arbitration as it has been used to assure the enforcement of regulations and agreements within an industry, see Kronstein, Business Arbitration-Instrument of Private Government, 54 Yale L. J. 36 (1945).

37 Ibid., at 40, 4I, where the author refers to the provisions for arbitration in the license agreement between the Carboloy Company and the Firth-Sterling Steel Company, and the agreements between Hartford-Empire Company and the Owens-Illinois Glass Company.

${ }^{8} 8$ "In the case of differences which may arise either directly or indirectly from the execution of the present contract no recourse may be made to the jurisdiction of any ordinary tribunals. These differences shall be settled by arbitration." Article XII of Franco-German Potash Agreement, December 29, 1926, Plummer, International Combines in Modern Industry, App. III (2d ed., I938). Similar provisions were inserted in the International Steel Agreement of I926 6 and the International Incandescent Lamp Cartel. Tbid., Appendixes I and IV. 
history of compulsory arbitration of contract disputes. This arbitration system, imposed by the producers upon exhibitors as a part of a contract, the signing of which was a condition precedent to the licensing of pictures, ${ }^{39}$ was held to violate the antitrust laws. $4^{\circ}$ In what proved to be a prophetic dictum the Court observed that arbitration, if properly administered, might be "well adapted to the needs of the movie industry." $4 \mathrm{r}$

A second type of arbitration was provided for by the consent decree. It was applicable at an earlier stage in the commercial process, and, it is submitted, its implications were far more serious. The arbitration machinery established in the decree operated not as a device for determining the meaning or application of the terms of a contract but as an implement for the fashioning of the contract itself. Thus, the arbitral boards were authorized to determine what provisions relating to runs and clearances should be inserted into exhibition contracts. The boards were to be the judges of what the contractual relations between the parties should be. The substitution of the opinion of an arbitral tribunal for free bargaining appeared reasonable, of course, if the producer domination of the industry was accepted as the only alternative. There was some color of reason to the argument that since there had been no "bargaining between equals" in the motion picture industry impartial arbitration was a salutary step.

It is doubtful, however, whether the arbitration device represented such a remarkable advance from the conditions existing prior to the decree. In determining the reasonableness of a clearance agreement, the standards which were to be followed by the arbitrators were cut from the pattern drawn by the dominant group in the industry. The decisions had been made long before the decree that preferential exhibition contracts should be awarded to those theaters which possessed certain characteristics of size, location, and seating capacity. These were the first-run theaters that charged the highest admission prices and maintained that price by the clearance device. The factors of size, location, prestige, and previous price and clearance history were the criteria which the arbitrators were to follow in determining the reasonableness of clearance. ${ }^{42}$ This reliance upon the established patterns in the industry was to be

39 Under the terms of the decree, arbitration boards had been established in $\mathrm{e}$ - ch of thirtytwo major cities. Each board consisted of three distributors and three exhibitor representatives, with a seventh arbitrator in case of a tie. In the event that an exhibitor refused to arbitrate a claim brought against him or to abide by any award, each distributor with whom he dealt might require him to post security of $\$ 500$ for each existing contract, under penalty of suspension of film delivery. Compliance with the will of the board was thus necessary for any exhibitor who wished to continue in business. See transcript of record, Paramount FamousLasky Corp. v. United States, 282 U.S. 30 (I930).

10 Paramount Famous-Lasky Corp. v. United States, 282 U.S. 30 (1930).

${ }_{4}$ Ibid., at 43. The Court did not object to arbitration as a means of settling disputes, but only to forcing it upon exhibitors as a prerequisite of continued existence within the industry.

42 "In determining whether any clearance complained of is unreasonable, the arbitrator shall take into consideration the following factors.... (I) The historical development of clearance in the particular area wherein the theatres involved are located; (2) The admission prices of the theatres involved; (3) The character and location of the theatres involved, in- 
expected. The arbitration of what the terms of a contract should be is of necessity hypostasized upon a set of industrial regulations and customs which are determinative of the relationships within the industry. Were free market conditions to prevail or to be approximated it would be impossible to establish a unified set of standards which would be determinative of the status of each member of the industry. ${ }^{43}$

This acceptance by the Government of the industrial structure which it had previously attacked with such vigor appears most clearly in the acknowledgment that clearance was necessary. "It is recognized," the decree stated, "that clearance, reasonable as to time and area, is essential in the distribution and exhibition of motion pictures." 44 It is indeed strange that the Government would sanction a device which is nothing more than a very effective pricefixing mechanism. The high admission prices at the prior-run theaters are protected by prohibiting other theaters in the same area from exhibiting the same feature within a certain period of time. 45 It is not necessary to debate the need for successive licensing of feature pictures through a series of runs ${ }^{46}$ in order to cast doubt upon the premises upon which the need for clearance is rested. It is argued that because a prior-run exhibitor is burdened with high overhead costs and is charged high rentals for his favored run he must be granted clearance protection in order to maintain high admission prices. The reference to

cluding size, type of entertainment, appointments, transit facilities, etc.; (4) The policy of operation of the theatres involved such as the showing of double features, gift nights, giveaways, premiums, cut rate tickets, lotteries, etc.; (5) The rental terms and license fees paid by the theatres involved and the revenues derived by the distributor defendant from such theatres; (6) The extent to which the theatres involved compete with each other for patronage; and (7) All other business considerations, except that the arbitrator shall disregard the fact that a theatre involved is affiliated with a distributor or with a circuit of theatres." Consent decree $\$ 8$. Thus the arbitrators could in no way upset the established pattern of distribution; their only function was to correct the judgment of the distributors.

${ }_{43}$ " $\mathrm{A}$ free and open market-had it been possible in the industry-could never have brought such usages into being." Hamilton, op. cit. supra, note 31 , at $5^{2}$.

44 Consent decree $\$ 8$.

${ }^{45}$ The price-fixing nature of clearance is conceded by its exponents. See, e.g., Lewis, The Motion Picture Industry zor et seq. (I933). The courts, however, have refused to hold that a clearance agreement was illegal per se. Unless the clearance agreement is part of a conspiracy to restrain trade, it is said that there is no violation of the Sherman Act. Westway Theatre v. Twentieth Century-Fox Film Corp., 3o F. Supp. 830 (Md., r940), aff'd II3 F. 2d 932

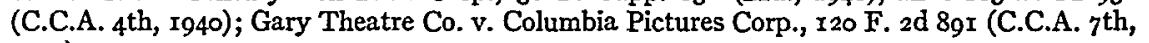
I94I).

However, in Bigelow v. RKO Radio Pictures, I50 F. 2d 877 (C.C.A. 7 th, 1945), rev'd on other grounds, 66 Sup. Ct. 574 ( $(946)$, the circuit court upheld the inference of conspiracy from little more than the showing of a uniform clearance schedule. .... "we think the [district] court was warranted in inferring a conspiracy from the fact that the defendant distributors were licensing the same theaters to exhibit films under precisely the same patterns of runs and clearances." I50 F. 2d 877,883 (C.C.A. 7th, r945); see note Ir, supra.

${ }^{4}$ Since the marginal cost of a positive print is considerably greater than the revenue obtained from its exhibition in any theater, it is said to be necessary that each print be licensed to a succession of theaters. See Bigelow v. RKO Radio Pictures, I50 F. 2d 877, 880 (C.C.A. 7 th, 1945). 
high rentals simply means that once the industry has determined that first runs shall bring high admissions it is justified in employing a device for effectively maintaining those prices. It would seem that if the cost of a choice location, expensive buildings, and equipment cannot be met without the aid of a rigid price-maintenance mechanism then the capital invested would be better employed in other fields. At least, it is doubtful whether the Department of Justice should have agreed that such a device is "essential."

The importance which the decree attached to the existing structure of the industry is underscored by the provisions restricting the right to arbitrate the run provisions in exhibition contracts. Section Io provided that only those complaints relating to theaters existing at the date of the decree could be heard by the arbitrators. Furthermore, if the theater was in existence at the time of the decree, in order to obtain the requested run it was necessary for the complaining exhibitor to prove either (a) that the theater specified in the complaint had operated on the run requested sometime between July, I935, and July, I940, or (b) that the theater had operated on the requested run sometime subsequent to the decree or (c) that a request had been filed for such a run previous to the decree. Such provisions insure the maintenance of the status quo in the industry. The position of each member of the industry is frozen; the entrance of newcomers is discouraged. This conditioning of privileges upon a previously acquired position in the industry is not consistent with a policy designed to encourage competitive enterprise such as might be expected in a consent decree under the Sherman Act. Indeed, there is a striking parallel between these run provisions and the apportionment of benefits and rights among parties to a cartel agreement in accordance with their previous status in the industry. ${ }^{47}$ Yet, given the Government's acceptance of the motion picture industry's clearance system, such restrictions upon the right to secure new runs is not surprising. Both are techniques by which any change in the pattern of the industry is effectively restrained.

The anti-competitive flavor of the decree was not limited to the provision for arbitration, the acceptance of clearance, and the restrictions upon the right to obtain an adjustment of runs. The specific restrictions upon blind selling and block booking were to be lifted after September I, I942, if a defendant could establish that competition from persons not selling in accordance with the provisions of the decree had "substantially and adversely affected" the defendant's business. The significant feature of this condition was that its operation was not limited to competition by the established producers who had not consented to the decree. The relief could be sought if there was competition from new distributors and producers. Thus, the advent of competition was to be the excuse for the re-establishment of trade practices which for years had been used to discourage competition.

${ }^{47}$ See Plummer, op. cit. supra, note 38, at c. 5; Berge, Cartels, Challenge to a Free World II9 (I944). 
The decree, grounded as it was upon the existing structure of the industry, could not be expected to eliminate the ills which afflicted the industry. The failure was not so serious, however, as the premise which the decree accepted, that the movie industry should be removed from the scope of the antitrust laws. ${ }^{8}$ Far from reflecting the policy behind the Sherman Act, the decree closely resembled the laws passed by other nations to regulate the operation of cartels.49 It is possible to speculate why the Government agreed to such a system of selfregulation. The concern that a long and costly suit might end in a decision vindicating the industry was paradoxically joined with a fear as to the economic dislocation that would follow a successful suit..$^{50}$ Furthermore, the Government itself apparently was not convinced that the unique characteristics of the movie industry could be adapted to a more competitive system than that which existed at the time of the decree. ${ }^{5 x}$ Yet it is submitted that only Congress might provide that the motion picture industry is to be relieved from the operation of the antitrust laws; ${ }^{52}$ it is not the responsibility of the Department of Justice to grant such an exemption.

The Government has now returned to the position taken in I938: there must be divestiture of exhibition houses from their producer-distributor owners. This is the only stand consistent with the Government's charges of trade discrimination and oligopoly. The attacks upon specific trade abuses did not seriously impair the structure of the industry; the consent decree candidly accepted it. As

${ }^{8}$ Cf. St. Louis Amusement Co. v. Paramount Pictures, 6x F. Supp. 854 (Mo., I945), in which the district court, rather reluctantly, rejected a contention that the decree itself was a violation of the Sherman Act.

49 The traditional approach of European governments to the cartelization of industry has been to enact laws giving governmental sanction to the already established system. See Pribram, Cartel Problems c. 6 (I935).

${ }^{50}$ The official reason for the Government's acquiescence in the decree was the desire "to provide a means for the elimination of unfair competitive practices in the industry without resorting to the more drastic remedy of divorcement." Antitrust Division, Public Statement, p. 8, October 29, 1940.

${ }^{2}$ The Government's position was especially surprising in view of the assertions at the time of filing the suit that a completely competitive industry was attainable. Antitrust Division, Public Statement, p. I3 et seq., July 20, 1938. Only a few months before the publication of the decree, Thurman Arnold, Assistant Attorney General of the United States in charge of the Antitrust Division, appeared before a subcommittee of the Senate Committee of the Judiciary to endorse S. 3735, a bill proposed by Senator Neely prohibiting producers or distributors from owning, controlling, or booking films for theaters. Mr. Arnold expressed the need for legislation of this sort because of the delay which had continually hampered the Government's prosecution of the present suit. When questioned as to the possibility of a settlement (such as the present decree), Mr. Arnold replied: "If they [the defendants] should submit it to the Department of Justice, I can see only one justification for submitting it to the court, since it is based on the continuance of this vertical combination. The suit we are prosecuting must not be dismissed, and therefore the only reason why we could accept such a plan would be that the industry would feel that only by such a plan could they survive at all. It is a thing that can be justified only as an emergency matter." Motion Picture Herald, pp. I4-I5 (April 27, 1940).

52 Compare the legislation exempting the insurance industry from the Sherman Act for a limited period. 59 Stat. $\$ 34$ (1945); I5 U.S.C.A. $\$$ I013 (Supp., I945). 
long as the producers have a financial interest in those houses which for years have been granted prior-run and clearance privileges there can be no competitive opportunity for new producers or independent exhibitors. The Government's demand for divestiture has been strengthened by the events of the last five years. The decisions in United States v. Crescent Amusement $C_{0.53}{ }^{53}$ and United States v. Schine Chain Theatres ${ }^{54}$ have established the propriety of divestiture as a method of eliminating restrictive practices in the industry. These decisions have rebutted the argument of the producer-distributors that divestiture of their exhibition holdings would leave them at the mercy of the exhibitor chains. The primary significance of these decisions, however, when taken in conjunction with the decision in Bigelow v. RKO Radio Pictures, ${ }^{55}$ is that they demonstrate the anti-competitive pattern of the industry.

The Government's concentration upon divestiture has, however, left undetermined its position in respect to other relief which would appear to be necessary if the Government's allegations are true..$^{56}$ Indeed, the thrust of the Government's arguments in the current proceedings has been somewhat confusing. In the first trial brief filed in September, 1945, there is almost no criticism of the anti-competitive flavor of the 1940 consent decree. 57 The Government did not criticize the system of arbitration or the provisions restricting the right to arbitrate runs. The position as to clearance was ambiguous. In December, $\mathrm{r} 945$, the Government filed a second and considerably longer brief..$^{8}$ There was a striking change in the thrust of this brief. The Government now questions the necessity of clearance, refers to the restrictions upon the right to arbitrate as "grandfather clauses," and, inferentially at least, suggests that

53323 U.S. 173 (r945). The Government obtained a decree breaking up the Crescent circuit, an unaffiliated exhibitor organization which dominated exhibition in about seventy towns in Alabama, Arkansas, Kentucky, Mississippi, and Tennessee. Furthermore, the defendants were enjoined from using their purchasing power to keep films from independent competitors, and from acquiring additional theaters, without the express permission of the district court.

5463 F. Supp. 229 (N.Y., r945). This was a companion action to the Crescent case, directed at a chain operating in the East and the Southeast. The decree was substantially identical to that finally approved in the Crescent case.

ss 66 Sup. Ct. 574 (1946); see notes II and 45, supra.

$5^{6}$ "In conclusion, we submit that the paramount purpose of this proceeding is to secure an adjudication of the validity of the integrated structure of the five producer-exhibitor defendants. Until the Court has decided that question and determined the general form that the dissolution of these combinations is to take, we do not believe that any final form of trade practice relief against all of the distributor defendants may be satisfactorily determined." Plaintiff's Second Brief, p. I34.

s7 The Government went no further than to state that its experience under the decree had demonstrated that "no decree would give adequate relief which did not include divorcement of the defendants' theatre operations from their other activities. . . ." Plaintiff's First Brief, at 4.

${ }^{8}$ In the oral argument, the Government explained the need for a second brief by saying that the first one, which had been printed by the defendants, had contained numerous typographical errors, and was of smaller print than the second brief. Arguments, 45-46. 
arbitration must go.59 Indeed, the Government has finally confessed that "the inadequacy of the existing decree to enforce the law lies principally in its failure to use Sherman Act criteria as a test of violation." 60

The Government, however, still concedes to the producer the right not only to choose those exhibitors who will be entitled to first runs but also to impose clearance restrictions upon subsequent runs. The only limit placed upon such actions is that they must not be the result of any agreement between a distributor and exhibitor as to the terms on which the distributor will serve his pictures to other exhibitors. ${ }^{6}$ The Government now contends that any such agreements are illegal per se under the decision in Interstate Circuit v. United States. ${ }^{62}$

It is doubtful whether divestiture coupled with an outlawing of agreements respecting runs and clearance will break down the stratified industrial system which has been constructed during the last twenty-five years. In some industries the divorcement of production and distribution from the retailing operations might stimulate competition and encourage the entrance of new capital. But in the motion picture industry the financial success of the feature film is determined to a large extent by the prestige of the theater exhibiting it. This prestige in turn has been due in large part to the years of favoritism practiced by the producer-distributors. Even were there divestiture and the abolition of agreements respecting runs and clearance, it is possible that a symbiotic relationship between established producers and first-run exhibitors would con-

${ }^{39}$ The brief still suggests the possibility of "reasonable" clearance agreements, and arbitration thereof. Plaintiff's Second Brief, at 123 et seq. Arguing orally, however, the Government attorneys demanded that all clearance agreements be prohibited. Arguments, 28, 30, 46 et seq.

That the court did not overlook the change in the Government's attitude is indicated by the following colloquy:

Mr. Marcus [attorney for the Government]: I shall now take up the question of clearance. Judge Hand: Take up the question of what?

Mr. Marcus: Clearance. Mr. Wright has already stated that the Government's position is that clearance agreements are illegal under the Sherman Act. Generally speaking there are two typesago?

Judge Hand: Have you been converted, too, from the state of original sin only a little while

Mr. Marcus: No, Your Honor.

Judge Hand: You mean you are pure from the beginning?

Arguments, $46-47$.

${ }^{60}$ Plaintiff's Second Brief, at 123.

6I "We feel that the distributor should be free to determine his run and clearance structure without making any express agreement with any exhibitor in the area." Robert L. Wright, Special Assistant to the Attorney General, Arguments, 28.

${ }^{62} 306$ U.S. 208 (I939). The majority of the Court held that agreements between a distributor and a prior-run exhibitor that no pictures would be licensed for subsequent runs except upon condition that the subsequent exhibitor maintain minimum admission prices and refrain from showing double features, were illegal and beyond the scope of the distributor's copyright. The majority did not hold that clearance agreements were illegal per se. Mr. Justice Roberts, dissenting, argued that the decision could mean only that any agreement with respect to clearance was illegal. Ibid., at 238 . The Government appears to rely upon Mr. Justice Roberts' reasoning. Arguments, at 49 . 
tinue, to the detriment of any exhibitors or producers seeking to enter the field or of exhibitors who might seek to secure a stronger position within the industry. The industry has been permitted to develop in a direction violative of the Sherman Act. A pattern has been established in which the rights of theaters are fixed regardless of their competitive efficiency. The same theaters have always received prior-run rights from the same producers. ${ }^{63}$ If the determination of the run and clearance structure is to be left to the "judgment" of the distributor as the Government suggests, it is doubtful whether there would be any significant change in the industrial system. ${ }^{64}$

It would seem necessary to couple the request for divestiture with a request that ( $I$ ) the right to first-run exhibition be determined by public auction and (2) all clearance between first and subsequent runs be abolished.

The price-fixing effect of clearance has been noted. So long as a producer may withhold film from subsequent runs, it is difficult to see how there can be a free market in the industry. By introducing an auction system, the right to have a first-run showing would depend solely upon the ability to pay. Once present prior-run holders know they can no longer count upon preferential treatment from established producers, they will have little motive for discriminating against new producers. Such an auction system would have to assume that the highest bidder would obtain the right to the exclusive showing of the film within a certain area. The economics of the industry and the acceptance of a system of prior runs for years probably prohibits the elimination of a successive-run pattern. In the large metropolitan areas it might be necessary to establish two or three areas within which bids would be taken for first runs. In the smaller towns all theaters should be entitled to participate in the auction. The application of such an auction system to subsequent runs would be more complicated but probably not so essential. The stratified nature of the industry depends in large part upon the rigidity of the first-run pattern. Once it is no longer certain that the same theaters will receive first-run rights from the same producers, the entire hierarchy will be shaken. Furthermore, the success with which the Gov-

${ }_{63}$ The problem of the prior-run status of certain theaters is confused by assumptions as to the right of a seller to choose his customers and to select exclusive agents. These same assumptions have appeared in other cases where preferential treatment has been the basis for allegations that the industrial structure violated the Sherman Act. Thus, the Associated Press argued that the exclusion of certain newspapers from its membership was a legitimate exercise of the right to choose those to whom service should be sold. In rejecting this contention the Supreme Court noted the difficulty of publishing a newspaper without AP service and remarked: "While it is true in a very general sense that one can dispose of his property as he pleases he cannot 'go beyond the exercise of this right, and by contracts or combinations, express or implied, unduly hinder or obstruct the free and natural tow of commerce in the channels of interstate trade." "Associated Press v. United States, 326 U.S. I, I5 (I945).

${ }_{64}$ "Mr. Wright [attorney for the Government]: $I$ think it is up to the distributor to handle it [clearance]. .... He would be left free, of course, to license his film to such exhibitors on such runs as he thought would give him the most revenue in the particular area where he was serving his prints.

Judge Goddard: Isn't that what he is doing now?" Arguments, 30. 
ernment has attacked the exhibition chains and the blow delivered to the "Chicago system" of release in the Bigelow case suggest that the small outlying exhibitor will now operate in a more competitive market.

Concededly, the introduction of an auction system would present serious practical problems. ${ }^{65}$ The current use of both a percentage of gross receipts and a flat fee as bases of the rental charge for film would require modification before there could be competitive bidding. The uncertain length of time for which any first-run showing would continue would require considerable flexibility in the auction system. The application of an auction system should be frankly experimental and, like the consent decree, should be subject to modification in a few years. By the end of that period the entrance of new producers and the custom of renting only on the basis of ability to pay might sufficiently loosen up the system so that compulsory rental to the highest bidder would no longer be necessary.

The legal justification for such an auction system must rest upon the argument that without such relief it is impossible to bring the industry within the competitive framework required by the Sherman Act. The Government has argued that the copyright does not give the holder the right to enter into restrictive agreements with exhibitors respecting the prices to be charged and the clearance to be granted. The basis for the Government's contention is the approach of the United States Supreme Court in the last eight years to abuses of the patent right. Where it has been demonstrated that the patent has been used as part of a system designed to restrain trade, the patent right has not removed the practices from the scope of the Sherman Act. ${ }^{66}$ It cannot be maintained that the copyright holder has any greater privileges than the patent holder. ${ }^{67}$ But it might be argued that in the absence of agreements between producers and exhibitors the copyright holder should be entitled to license the film to whomever he chose. However, if, as appears probable, the same industrial structure will exist irrespective of divestiture and the abolition of producer-exhibitor agreements, the copyright should not prevent the application of measures necessary to introduce competition into the industry. To require compulsory licensing would appear no more drastic than the relief afforded in patent cases. Where there has been abuse of the patent, the holder has been denied the right to sue for infringement until he is able to show that the effects of the misuse have been dissipated; until such time the exclusive right to sell and manufacture is denied

${ }_{65}$ Evidently the Government has considered the possibility of a compulsory auction, but is reluctant to indorse it. On being questioned whether he would favor auctioning pictures, Wright merely said that such would not be inconsistent with the purposes of the Sherman Act. Arguments, I2.

${ }^{66}$ Hartford-Empire Co. v. United States, 323 U.S. 386 (1945); United States v. Masonite Corp., 316 U.S. 265 (1942); Ethyl Gasoline Corp. v. United States, 309 U.S. 436 (I939).

${ }^{67}$ If anything, his monopoly is more limited than that of the patentee. Straus v. American Publishers' Ass'n, 23I U.S. 222 (I9I3); Bobbs-Merrill Co. v. Straus, 210 U.S. 339 (I908); Plaintiff's Second Brief II8. 
him. ${ }^{68}$ If the Government can demonstrate ( $x$ ) that the copyright has been used as part of a nation-wide system which is violative of the Sherman Act, and (2) that without compulsory licensing there is no assurance that a competitive pattern can be established in the industry, the copyright should not stand in the way of such relief. Indeed, the relief suggested for the motion picture industry would be more limited than that granted in the patent cases. A strict application of the doctrine of those cases would completely abrogate the producer's copyright; he would be unable to prevent a rival from producing any of his photoplays. Under compulsory licensing he would still have the exclusive right to produce the film and he would still be entitled to grant an exclusive license for the first-run exhibition of the film. He would not, however, be permitted to deny the right to the exclusive showing to the exhibitor who was able to pay the highest price.

The decision in the conflict between the competitive ideals of the Sherman Act and the system established in the motion picture industry appears to be reaching a climax after thirty years of struggle. Although uncertainty and confusion still may be found in the Government's approach, it appears, at last, that the Department of Justice may accept as its standard the words of Mr. Justice Douglas in the Crescent case:

It is not for us .... to pick and choose between competing business and economic theories in applying .... [the Sherman Act.] Congress has made that choice. It has declared that the rule of trade and commerce should be competition, not combination.69

However, if the court in the instant case should refuse to grant the Government's request for relief, it may be due in part to the Government's acquiescence in the consent decree and the uncertainty reflected in the Government's current attack upon the structure of the industry.

${ }^{68}$ Morton Salt Co. v. G. S. Suppiger Co., 314 U.S. 488 (1942); Mercoid Corp. v. Minneapolis-Honeywell Regulator Co., 320 U.S. 680 (r944); Mercoid Corp. v. Mid-Continent Investment Co., 320 U.S. 66I (I944); B. B. Chemical Co. v. Ellis, 3 I4 U.S. 495 (1942); cf. United States v. Vehicular Parking, Ltd., 6I F. Supp. 656 (Del., I945).

${ }^{69} 323$ U.S. I73, r87 (1945). 